\title{
A survey of entomopathogenic nematodes of the families Steinernematidae and Heterorhabditidae (Nematoda: Rhabditida) in the north-west of Iran
}

\author{
Naser EIVAZIAN KARY ${ }^{1, *}$, Gholamreza NIKNAM ${ }^{2}$, Christine T. GRIFFIN ${ }^{3}$, \\ Seyed Abolgasem MoHAMmadi ${ }^{4}$ and Mohammad MoghadDAM ${ }^{4}$ \\ ${ }^{1}$ Department of Plant Protection, Faculty of Science, University of Tarbiat Moallem of Azarbaijan, Tabriz, Iran \\ ${ }^{2}$ Department of Plant Protection, Faculty of Agriculture, University of Tabriz, Tabriz 51664, Iran \\ ${ }^{3}$ Department of Biology, National University of Ireland, Maynooth, Co. Kildare, Ireland \\ ${ }^{4}$ Department of Agronomy and Plant Breeding, Faculty of Agriculture, University of Tabriz, Tabriz, 51664, Iran
}

Received: 11 January 2008; revised: 5 May 2008 Accepted for publication: 6 May 2008

\begin{abstract}
Summary - During 2002-2004, a survey of entomopathogenic nematodes was conducted for the first time in Iran throughout the three provinces in the north-west of the country. Soil samples were tested for the presence of steinernematid and heterorhabditid nematodes by baiting with Galleria mellonella larvae. Of the 833 soil samples studied 27 were positive for entomopathogenic nematodes (3.2\%), with $17(2.0 \%)$ containing Heterorhabditis and ten (1.2\%) Steinernema isolates. Morphological and molecular studies were carried out to characterise isolates. The Heterorhabditis isolates were identified as Heterorhabditis bacteriophora and Steinernema as Steinernema carpocapsae, S. bicornutum and S. feltiae. Heterorhabditis bacteriophora was the most common species, which was isolated from 17 sites across the three provinces. Steinernema feltiae was the most common species of Steinernema, which was isolated from eight sites but in only two provinces. Steinernema carpocapsae and S. bicornutum were each isolated from only one site. Steinernema spp. were isolated mainly from orchards and grasslands but Heterorhabditis was isolated mainly from grasslands and alfalfa fields.
\end{abstract}

Keywords - Heterorhabditis bacteriophora, Steinernema bicornutum, Steinernema carpocapsae, Steinernema feltiae.

Entomopathogenic nematodes (EPN) from Heterorhabditidae (Poinar, 1976) and Steinernematidae (Travassos, 1927) families are obligate insect parasites, which can infect and kill a broad range of insect hosts (Kaya \& Gaugler, 1993). These nematodes are symbiotically associated with entomopathogenic bacteria Photorhabdus (Boemare et al., 1993) and Xenorhabdus (Thomas \& Poinar, 1979). These nematodes have been used successfully as biological control agents of insect pests.

The only life cycle difference between Heterorhabditis and Steinernema is in the first generation. Steinernema species are amphimictic; this means that for successful reproduction, male and female infective juveniles (IJ) must enter the host, whereas Heterorhabditis species are hermaphroditic and only one IJ in the host is sufficient for successful reproduction. In the second generation of both nematode genera reproduction is amphimictic (Poinar,
1990). However, a hermaphroditic steinernematid species was isolated from Indonesia by Griffin et al. (2001).

Entomopathogenic nematodes have a global distribution (Hominick, 2002). The only continent where they have not been found is Antarctica. However, biotic and abiotic factors cause the distribution EPN to differ across different regions. Factors such as soil texture, temperature and host availability are thought to be important in determining their distribution (Hominick \& Briscoe, 1990; Griffin et al., 1991; Stock et al., 1999).

The current survey is the first to be conducted in Iran, and focused on three of the 30 provinces, East Azarbaijan, West Azarbaijan and Ardabil. The goal of this study was to survey entomopathogenic nematodes from the families Heterorhabditidae and Steinernematidae in the north-west of Iran, to identify the species present and to distinguish their ecosystem, habitat and soil type preferences.

\footnotetext{
* Corresponding author, e-mail: eivazian@azaruniv.edu
} 


\section{Materials and methods}

\section{COLLECTION OF SOIL SAMPLES}

In total, 833 soil samples were collected randomly from different cultivated and non-cultivated areas of north-west Iran during 2002-2004. Each soil sample was a composite of 5-20 random sub-samples taken in the same location, but at least $10 \mathrm{~m}$ away from each other and to a depth of $30 \mathrm{~cm}$, using a small shovel. Between samples, the shovel was thoroughly rinsed with water and air dried to prevent contamination of the next sampling unit. The soil was thoroughly mixed on a plastic sheet and half of each sample was used for extraction of EPN.

\section{NEMATODE ISOLATION AND PROPAGATION}

EPN were recovered from soil samples using an insect baiting method, described by Bedding and Akhurst (1975). Ten last instar Galleria mellonella (L.) larvae were placed in a $300 \mathrm{ml}$ jar containing moistened soil obtained from one of the samples and stored at room temperature $\left(25 \pm 2^{\circ} \mathrm{C}\right)$ for 2 weeks. The traps were checked every two days from the 5 th day. Dead larvae from each container were placed in White (1929) traps to collect emerging IJ and were replaced by fresh larvae. To verify the pathogenicity of collected nematodes and to establish new cultures, emerging nematodes were pooled for each sample and used to infect fresh G. mellonella larvae.

\section{TAXONOMIC STUDIES - MORPHOLOGICAL CHARACTERISATION}

For morphological studies, nematodes were examined live or heat killed in Ringer's solution heated to $60^{\circ} \mathrm{C}$. All nematodes used in this study were reared in G. mellonella larvae. Ten G. mellonella larvae were exposed to $c a 1000$ IJ in a Petri dish lined with two moistened filter papers at room temperature $\left(25 \pm 3^{\circ} \mathrm{C}\right)$. For isolating mature females and males of the first and second generations, the infected larvae were dissected in Ringer's solution 4 and 7 days after infection, respectively.

Heat-killed nematodes were placed in triethanolaminformalin (TAF) fixative (Kaya \& Stock, 1997) and processed to anhydrous glycerine for mounting by a slow evaporation method (Poinar, 1976). Morphology and morphometric studies were conducted using an Olympus BX41 microscope equipped with differential interference elements and drawing tube.

The following characters were measured in males and/or IJ: total body length; maximum body diam.; anal body diam.; excretory pore position; distance from anterior end to base of pharynx; gubernaculum length; spicule length (measured along the curvature in a line along the centre of the spicule); gubernaculum length divided by spicule length (\%); distance from anterior end to nerve ring position; ratio a (total body length divided by maximum body diam.); ratio $b$ (total body length divided by distance from anterior end to base of pharynx); ratio c (body length divided by tail length); ratio D (excretory pore position divided by distance from anterior end to base of pharynx); ratio $\mathrm{E}$ (excretory pore position divided by tail length); spicule length divided by anal body diam. and tail length (measured with consideration of the extra cuticular sheath of the second-stage juvenile).

Morphological identification was made using taxonomic criteria suggested by Stock and Kaya (1996) and Hominick et al. (1997). Additionally, morphological features of males and IJ of representative isolates of each species group were examined using scanning electron microscopy. For this purpose specimens were processed following protocols described by Nguyen and Smart (1995).

\section{TAXONOMIC STUDIES - MOLECULAR CHARACTERISATION}

\section{Extraction of DNA}

DNA was extracted from a single IJ with the following method: the nematode was crushed in $15 \mu \mathrm{l} 1 \times$ PCR Buffer and transferred to a precooled sterilised $0.2 \mathrm{ml}$ tube containing $10 \mu \mathrm{l}$ of the same buffer. The tube was incubated at $-70^{\circ} \mathrm{C}$ for $15 \mathrm{~min}$ and thawed at $60^{\circ} \mathrm{C}$ then inoculated with $2 \mu \mathrm{l}$ of $60 \mu \mathrm{g} \mathrm{ml}^{-1}$ proteinase $\mathrm{K}$. The tube was incubated at $65^{\circ} \mathrm{C}$ for $2 \mathrm{~h}$, and then heated at $95^{\circ} \mathrm{C}$ for $15 \mathrm{~min}$. After centrifugation at $16000 \mathrm{~g}$ for $15 \mathrm{~min}$, the supernatant containing nematode DNA was collected and stored at $-70^{\circ} \mathrm{C}$ until use.

\section{PCR amplification and sequencing}

The ITS and 28s regions were amplified by PCR in a $50 \mu \mathrm{l}$ reaction containing: $15 \mu \mathrm{l}$ of worm lysis mix, $5 \mu \mathrm{l}$ of 10× PCR Buffer, $2 \mu \mathrm{l}$ of dNTP mix, 1.2 unit of Taq DNA polymerase, $1 \mu \mathrm{l}$ of each primer and double distilled water to final volume. The forward primer TW81 (5'-GTTTCCGTAGGTGAACCTGC-3') and the reverse primer AB28 (5'-ATATGCTTAAGTTCAGCGGGT-3') were used in the PCR reaction for amplification of the complete ITS region (Joyce et al., 1994). The primers for the amplification of a partial 28S rDNA were $5^{\prime}-\mathrm{CG}$ ATAGCGAACAAGTACCGAGAG-3' (forward) and 5'- 
CCTGCTCAGGCATAGTTCACCATC-3' (reverse) (Qiu et al., 2004).

Amplified products were purified using a Qiagen Purification kit (Qiagen, Leusden, The Netherlands). Purified DNA was sequenced with Barcode Sequencing Service of AGOWA Inc. The DNA sequences were edited with Chromas 2.01. The sequences are deposited in Genbank (Table 1).

\section{Sequence alignment and phylogenetic analysis}

The DNA sequences were aligned using Clustal X 1.64 (Thompson et al., 1997) with the (ITS1-5.8S-ITS2 for Heterorhabditis spp. and 28S for Steinernema spp.) sequences of other Heterorhabditis and Steinernema species obtained from GenBank. For Heterorhabditis analysis, sequences of the following taxa were used: Heterorhabditis bacteriophora Poinar, 1976 (EF043438); H. indica Poinar et al., 1992 (EF043445); H. megidis Poinar et al., 1987 (EU163272); H. downesi Stock et al., 2002 (EF043442);
H. marelatus Liu \& Berry, 1996 (EF043441); H. zealandica Poinar, 1990 (EF530041) and Cervidellus alutus (Siddiqi, 1993) as the outgroup taxon (AF331911).

For Steinernema analysis we used some of the sequences which have been deposited in GenBank by Stock et al. (2001) including S. affine (Bovien, 1937) (AF331899), S. ceratophorum Jian, Reid \& Hunt, 1997 (AF331888), S. cubanum Mráček, Hernandez \& Boemare, 1994 (AF331889), S. intermedium (Poinar, 1986) (AF331909), S. karii Waturu, Hunt \& Reid, 1997 (AF331902), S. monticolum Stock, Choo \& Kaya, 1997 (AF331895), S. oregonense Liu \& Berry, 1996 (AF331891), S. riobrave Cabanillas, Poinar \& Raulston, 1994 (AF331893), S. scapterisci Nguyen \& Smart, 1990 (AF331898), S. feltiae (Filipjev, 1934) (AF331906), S. carpocapsae (Weiser, 1955) (AF331900), S. bicornutum Tallosi, Peters \& Ehlers, 1995 (AF331904) and Caenorhabditis elegans (Maupas, 1899) as the outgroup taxon (X03680).

Table 1. Location, vegetation and soil type of sites with entomopathogenic nematodes of the genera Heterorhabditis and Steinernema.

\begin{tabular}{|c|c|c|c|c|c|}
\hline Species (GenBank Accession No.) & Isolate & Province & Locality & Vegetation & Soil type \\
\hline H. bacteriophora (EU598222) & IRA1 & East Azarbaijan & Jolfa & Alfalfa & sandy loam \\
\hline H. bacteriophora (EU598223) & IRA2 & East Azarbaijan & Marand & Alfalfa & sandy clay loam \\
\hline H. bacteriophora (EU516355) & IRA3 & East Azarbaijan & Marageh & Alfalfa & sandy loam \\
\hline H. bacteriophora (EU598224) & IRA5 & East Azarbaijan & Marageh & Orchard & clay loam \\
\hline H. bacteriophora (EU598225) & IRA6 & East Azarbaijan & Marand & Orchard & sandy clay loam \\
\hline H. bacteriophora (EU598226) & IRA8 & East Azarbaijan & Malekan & Grassland & clay loam \\
\hline H. bacteriophora (EU598227) & IRA10 & East Azarbaijan & Oskoo & Orchard & sandy clay loam \\
\hline H. bacteriophora (EU598228) & IRA12 & West Azarbaijan & Ormiyeh & Grassland & sandy loam \\
\hline H. bacteriophora (EU598229) & IRA13 & West Azarbaijan & Ormiyeh & Grassland & sandy clay loam \\
\hline H. bacteriophora (EU598230) & IRA16 & East Azarbaijan & Bonab & Grassland & sandy clay loam \\
\hline H. bacteriophora (EU598231) & IRA19 & Ardabil & Meshgin shahr & Grassland & sandy clay loam \\
\hline H. bacteriophora (EU598232) & IRA24 & East Azarbaijan & Ahar & Grassland & sandy loam \\
\hline H. bacteriophora (EU598233) & IRA26 & East Azarbaijan & Ahar & Alfalfa & sandy clay loam \\
\hline H. bacteriophora (EU598234) & IRA29 & East Azarbaijan & Kaleibar & Alfalfa & sandy clay loam \\
\hline H. bacteriophora (EU598235) & IRA38 & East Azarbaijan & Ajab shir & Alfalfa & sandy loam \\
\hline H. bacteriophora (EU598236) & IRA40 & East Azarbaijan & Mianeh & Grassland & sandy loam \\
\hline H. bacteriophora (EU598237) & IRA41 & East Azarbaijan & Bostan abad & Vegetable & sandy loam \\
\hline S. bicornutum (EU598242) & IRA7 & East Azarbaijan & Marand & Alfalfa & sandy clay loam \\
\hline S. carpocapsae (EU598241) & IRA18 & Ardabil & Meshgin shahr & Orchard & sandy clay loam \\
\hline S. feltiae (EU598243) & IRA17 & East Azarbaijan & Varzgan & Grassland & sandy clay loam \\
\hline S. feltiae (EU598244) & IRA21 & East Azarbaijan & Ahar & Grassland & sandy clay loam \\
\hline S. feltiae (EU598245) & IRA22 & East Azarbaijan & Ahar & Grassland & sandy clay loam \\
\hline S. feltiae (EU598246) & IRA23 & East Azarbaijan & Sarab & Cropland & sandy loam \\
\hline S. feltiae (EU598247) & IRA25 & East Azarbaijan & Ahar & Alfalfa & sandy loam \\
\hline S. feltiae (EU598248) & IRA28 & East Azarbaijan & Shabestar & Orchard & sandy clay loam \\
\hline S. feltiae (EU598249) & IRA30 & East Azarbaijan & Heris & Orchard & sandy loam \\
\hline S. feltiae (EU598250) & IRA34 & Ardabil & Meshgin shahr & Orchard & sandy clay loam \\
\hline
\end{tabular}


Molecular phylogenetic relationships were obtained by equally weighted maximum parsimony (MP) and maximum likelihood (ML) using PAUP* 4.0b8 (Swofford, 1998). MP was performed with a heuristic search with the following setting: one hundred replicates of random taxon addition (RTA), tree-bisection-reconnection (TBR) branch swapping, multiple trees retained, no steepest descent and accelerated transformation. All data were assumed to be unordered, all characters were treated as equally weighted, and gaps were treated as missing data. For ML analysis, the appropriate substitution model of DNA evolution that best fitted the data set was determined by the Akaike Information Criterion with Model Test 3.06 (Posada \& Crandall, 1998). Bootstrap analysis with 1000 replicates was conducted as a measure of support for individual clades for MP and ML trees (Phan et al., 2003).

\section{CROSS-BREEDING TESTS}

To further confirm the identity of the Steinernema isolates, cross-breeding tests were performed between at least one representative isolate of each species group, with known isolates of the species group to which they were provisionally assigned, using the haemolymph hanging drop technique (Poinar, 1967). The following species were used to confirm their identity: S. feltiae (4CFMO strain), S. carpocapsae (All strain) and S. bicornutum (strain Azar4).

For each treatment an individual IJ from each population was transferred into a drop of haemolymph, from $G$. mellonella larvae, on the under surface of the lid of a small Petri dish. The transfer was carried out under a dissecting microscope. Two $\mathrm{ml}$ of sterile water was added to each Petri dish and the Petri dishes were sealed with parafilm. After 3 days the male from one isolate was transferred to a drop containing a female of a known species and vice versa. Self-cross controls were also conducted in the same way. Fifteen replicates were conducted for each treatment and control. The Petri dishes were then incubated at $20^{\circ} \mathrm{C}$ for 2 weeks. The reproduction of the nematodes was observed and recorded during the experimental period. The experiment was repeated twice.

\section{Results}

\section{GEOGRAPHICAL SOURCES OF NEMATODES}

Entomopathogenic nematodes were recovered from 27 sites $(3.2 \%) ; 17$ sites $(2.0 \%)$ were positive for the occur-

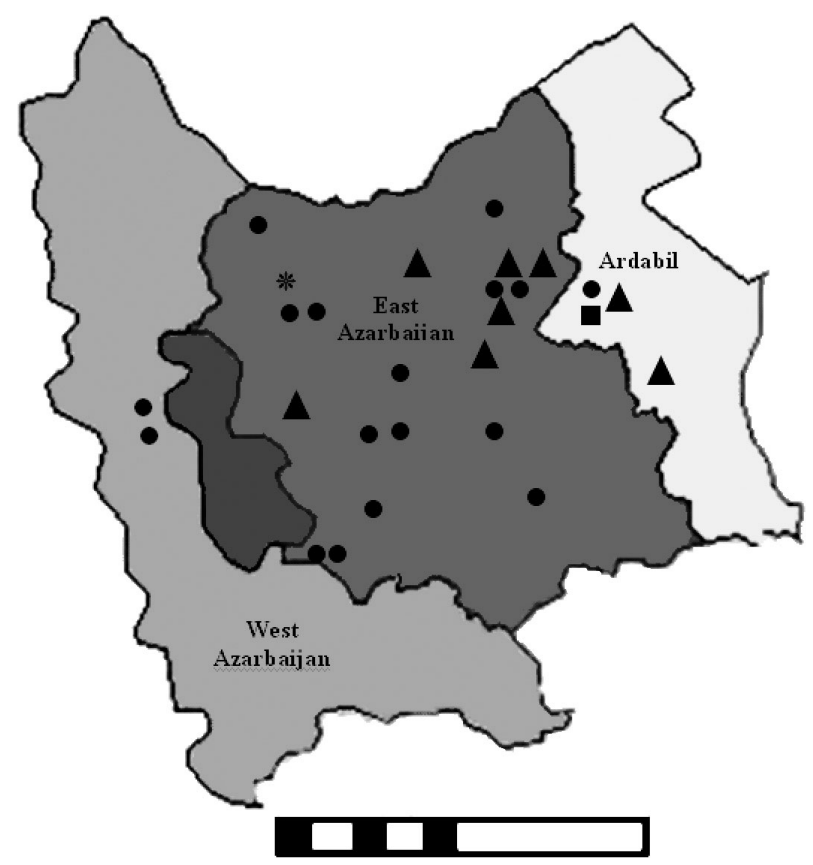

Fig. 1. Distribution of entomopathogenic nematodes in the north-west of Iran. The names represent the three provinces (map scale $250 \mathrm{~km}$ ). Heterorhabditis bacteriophora; - Steinernema carpocapsae; * S. bicornutum; $\boldsymbol{\Delta}$ S. feltiae.

rence of heterorhabditids and ten sites $(1.2 \%)$ for steinernematids (Fig. 1; Table 1). Based on morphological and molecular characterisation one species of Heterorhabditis and three distinct species groups of Steinernema were found. All Heterorhabditis isolates were identified as $H$. bacteriophora and Steinernema species groups as $S$. carpocapsae, S. bicornutum and S. feltiae. Among steinernematids, $S$. feltiae was recovered from eight sites (80\% of the steinernematids found) but $S$. carpocapsae and $S$. bicornutum were each isolated from only one site. No sample yielded more than one species of entomopathogenic nematode.

The majority of $H$. bacteriophora isolates were found in grasslands and alfalfa fields (grasslands $41.2 \%$, alfalfa fields $35.3 \%$ ). Orchards (mainly apple) and vegetable plots yielded the remaining positive samples. Steinernema feltiae was isolated mainly from orchards and grasslands in similar proportion (37.5\%) followed by alfalfa fields and cereals (12.5\%). Steinernema carpocapsae and S. bicornutum were isolated from an orchard and alfalfa field, respectively (Table 1).

In terms of species diversity, orchards and alfalfa fields displayed the greatest diversity of species: $H$. bacteriophora, S. feltiae and S. carpocapsae in orchards, and the 


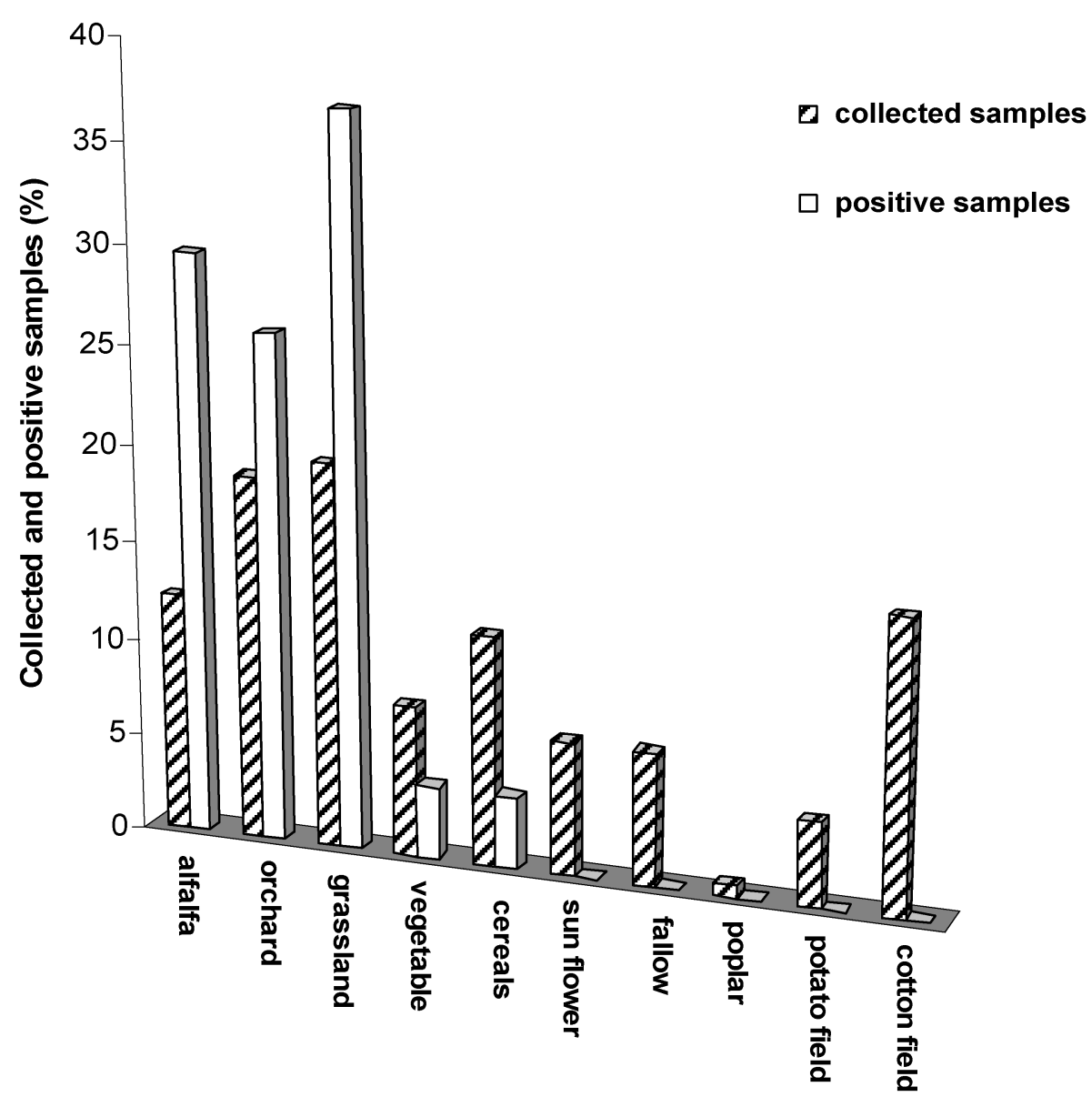

Fig. 2. Percentages of soil samples from different habitats collected and positive for entomopathogenic nematodes. Total number of samples taken: 833. Total number of positive samples: 27.

alfalfa fields were represented by $H$. bacteriophora, $S$. feltiae and S. bicornutum.

In terms of EPN recovery there was a significant difference at $P<0.05$ between habitats when tested with chi-square $\left(\chi^{2}=20.58, \mathrm{df}=9\right)$. Grassland showed the highest recovery rate $(1.2 \%)$ followed by alfalfa field $(0.96 \%)$, orchards $(0.84 \%)$, cropland $(0.12 \%)$ and vegetable $(0.12 \%)$ (Fig. 2). The habitats sunflower, fallow, poplar, potato field and cotton field were completely negative for nematodes.

The survey was only conducted in 8 months of the year because in other months sampling was not possible due to weather conditions. In every month of sampling we found sites with EPN. A chi-square test for association between sampling period and frequency of nematode recovery showed significance at $P<0.01\left(\chi^{2}=24.49\right.$, df $\left.=7\right)$. EPN recovery was highest in May $(40.7 \%)$ followed by
April (25.9\%), October (11.1\%), September (7.4\%) and June, July, August and November (3.7\%) (Fig. 3).

A chi-square test for association between soil texture and frequency of nematode recovery showed significance at $P<0.01\left(\chi^{2}=16.18, \mathrm{df}=3\right)$. EPN recovery in sandy-clay-loam soil $(55.5 \%)$ was higher than in other soil textures. There were no positive samples from clay soil (Fig. 4).

\section{Discussion}

The present study records for the first time the occurrence of EPN in Iran. Iran, which covers an area $1648195 \mathrm{~km}^{2}$, has a variety of different climatic regions. It stretches from Khazar Lake (the Caspian Sea) in the north, bordered by forest with moderate temperatures and 


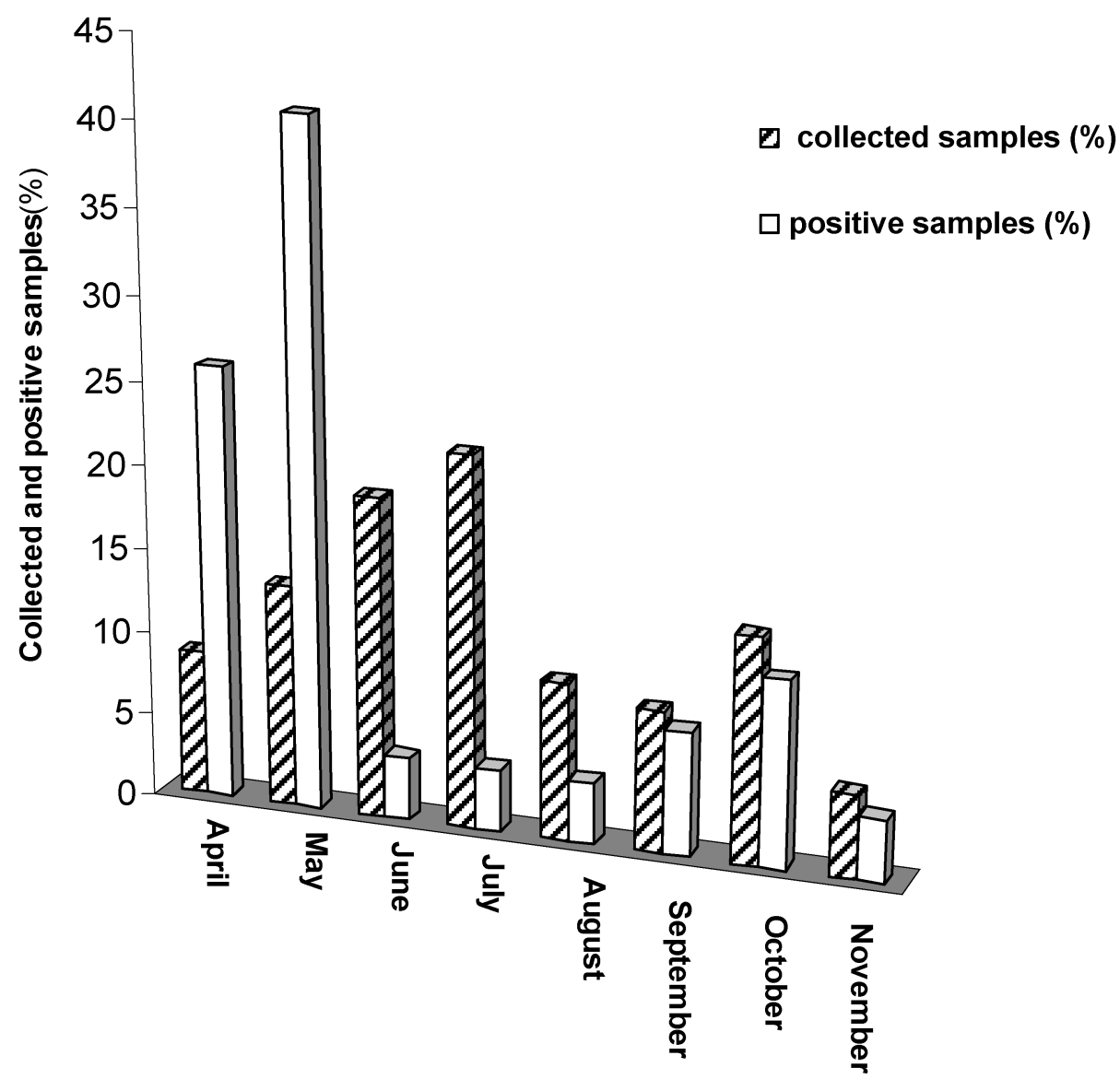

Fig. 3. Percentages of soil samples and positive for entomopathogenic nematodes in different months. Total number of samples taken: 833. Total number of positive samples: 27.
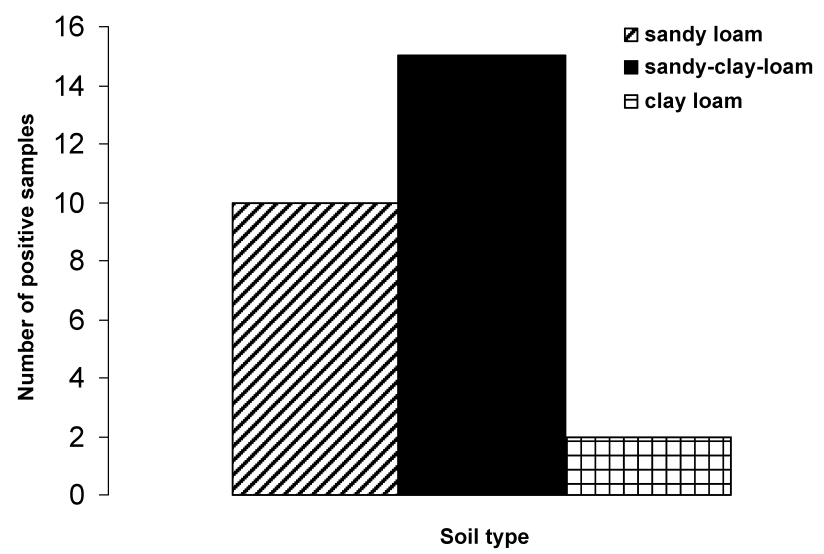

Fig. 4. Recovery of entomopathogenic nematodes from different soil types.

high humidity, to the Persian Gulf in the south, which has high temperature and humidity. The multiplicity of cli- matic zones makes it suitable for a wide variety of organisms. More than 2000 plant species grow in Iran. With such high plant diversity, which also results in a high diversity of insects, it is reasonable to suppose that Iran could harbour a number of different species and strains of EPN.

The north-west of Iran is a mountainous region with a cool continental climate. The region shares a border with Turkey, where three surveys have been conducted with the isolation of several known EPN species and at least one new species (Hazir et al., 2003a). Özer et al. (1995) recovered $S$. feltiae from the coast of the Black Sea, and Susurluk et al. (2002) isolated H. bacteriophora, a Heterorhabditis sp. and S. feltiae from Ankara. Hazir et al. (2003a) isolated H. bacteriophora, S. feltiae, S. affine and an undescribed Steinernema species from Turkey. Hazir et al. (2003b) subsequently described the new species as S. anatoliense. In their survey the most common species 
was $S$. feltiae, which was isolated from ten sites in six regions, followed by $H$. bacteriophora from seven sites in seven regions, $S$. affine from four sites in two regions and $S$. anatoliense from one site.

The first goal of the present work was to identify native species of EPN. In biological control programmes, using native biocontrol agents is often preferable to using exotic ones, since they are adapted to local conditions. Novel species and strains may have superior traits, making them suitable for direct commercial exploitation or as a source of genetic diversity for breeding improved strains (Choo et al., 1995).

Although EPN were recovered at a low rate $(3 \%$ of sites) in our study, we isolated four species from a somewhat small region with variable climate and vegetation. One reason for this low recovery rate could be that only Galleria mellonella was used as a trap insect, and it may not be an appropriate host for all EPN species/strains (Spiridonov \& Moens, 1999). Using only room temperature for baiting the soil samples could be another important reason. However, such a low recovery rate is not unusual and has been recorded in some other surveys conducted in other regions of the world (Choo et al., 1995; Rosa et al., 2000; Hazir et al., 2003a).

The habitats with high EPN recovery, such as grassland, orchard and alfalfa, were ones in which chemical control usage was low. We conclude that agricultural regions with high chemical pest control input have a lower recovery rate of EPN compared with areas with less chemical use.
Chemical pesticides can impact on EPN both directly and indirectly, by reducing host abundance.

Heterorhabditis bacteriophora was the most common and widely distributed entomopathogenic nematode in the north-west of Iran, followed by S. feltiae. Both of these species are widely distributed in the world (Hominick et al., 1996; Adams et al., 2006). Steinernema feltiae is widely distributed in temperate regions, whilst $H$. bacteriophora typically occurs in regions with continental and mediterranean climates (Hominick, 2002). Heterorhabditis appears to be the dominant EPN genus in mediterranean countries of the Middle East, such as West Bank Palestinian Territory and Egypt (Glazer et al., 1991; Iraki et al., 2000; Salama \& Abd-Elgawad, 2001).

The north-west of Iran is a mountainous region with a temperate-cold climate in which the annual temperature can range from -20 to $39^{\circ} \mathrm{C}$ (Table 2). We found H. bacteriophora at 17 sites with four different habitats (alfalfa, orchard, vegetable and grassland) and with some differences in climate and, therefore, it is likely that the respective isolates may have different ecological traits. For example, there is a large difference between Mianeh and Kaleibar in the number of days with maximum temperature equal to $30^{\circ} \mathrm{C}$ and above, 128 and 14, respectively (Fig. 5); therefore, the two $H$. bacteriophora strains from these localities may have different heat tolerances and survival rates. Different nematode species/strains have different temperature optima and ranges for activity and survival (e.g., Grewal et al., 1994; Griffin \& Downes, 1994).

Table 2. Characteristics of some of the sampling localities positive for entomopathogenic nematodes.

Locality

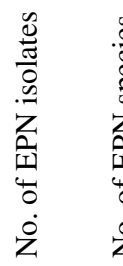

Oิ

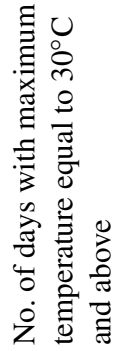
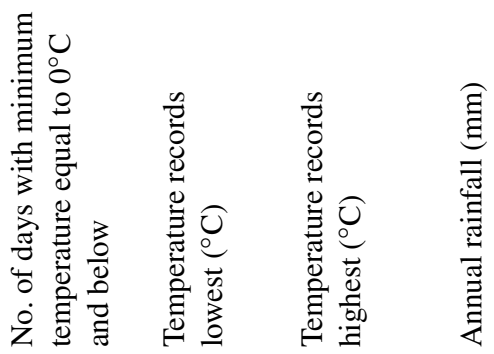

\begin{tabular}{|c|c|c|c|c|c|c|c|c|c|c|c|}
\hline Ahar & 5 & 2 & Apr 2003 & 1390 & 5.5 & 15.8 & 20 & 104 & -14 & 31.2 & 274.3 \\
\hline Kaleibar & 1 & 1 & June 2003 & 1796 & 2.8 & 14.2 & 14 & $*$ & $*$ & $*$ & $*$ \\
\hline Marageh & 2 & 1 & Sep 2003 & 1477.7 & 8.3 & 19.2 & 84 & 84 & -8.6 & 39.8 & 249.2 \\
\hline Meshgin shahr & 3 & 3 & May 2003 & 1568.5 & 5.2 & 14.4 & 6 & 114 & -10.6 & 37.4 & 362.3 \\
\hline Mianeh & 1 & 1 & June 2003 & 1110 & 7.6 & 20.9 & 128 & 82 & -13.8 & 38.6 & 276.6 \\
\hline Ormiyeh & 2 & 1 & June 2003 & 1313 & 5.5 & 17.8 & 58 & 110 & -9.2 & & 296.1 \\
\hline Oskoo & 1 & 1 & July 2002 & 1361 & 7.7 & 18.8 & 94 & 79 & -16 & 33.8 & 218.8 \\
\hline Sarab & 1 & 1 & Aug 2004 & 1682 & 1.8 & 15.7 & 27 & 149 & -20.6 & 33.6 & 287.5 \\
\hline
\end{tabular}

\footnotetext{
* Data not available.
} 


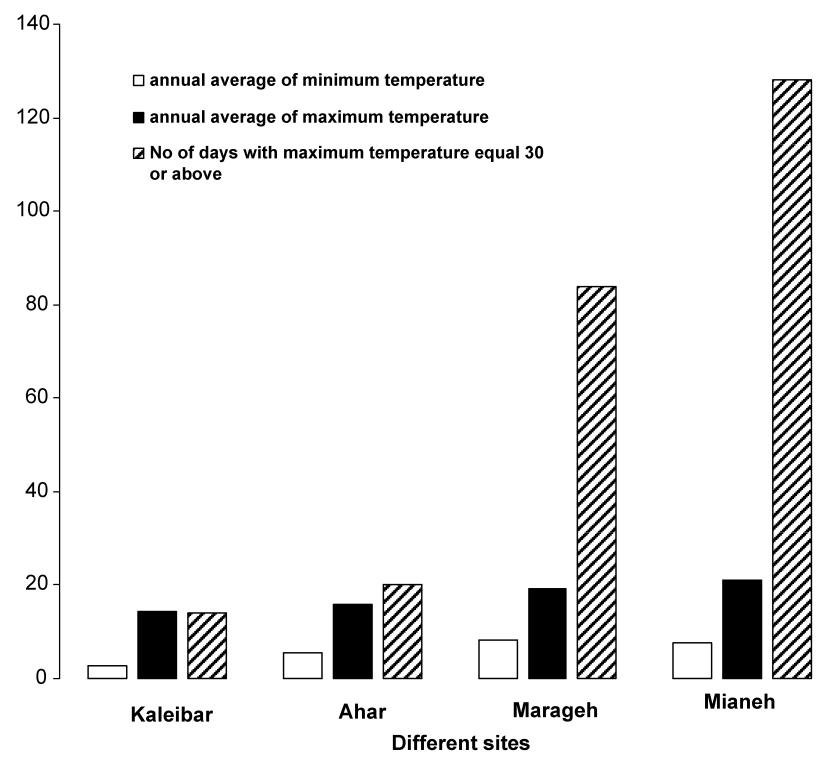

Fig. 5. Some meteorological factors at four sites from which Heterorhabditis bacteriophora was recovered.

Steinernema carpocapsae and S. bicornutum were each found at only one site, in orchard and alfalfa field, respectively. The reason for the low recovery of these two species is not known. Steinernema carpocapsae appears to have a global distribution but sometimes at low frequency as in central and northern Europe (Hominick, 2002). This species, originally described as indigenous to the Czech Republic, was not recovered by Mráček and Becvar (2000) even though they sampled intensively in suitable habitats, including the type locality. In an extensive survey of Germany, $S$. carpocapsae was found at only one of 1193 sites (Sturhan, 1999), a recovery rate similar to that of the present survey.

The natural hosts of EPN in north-west Iran are unknown, but alfalfa weevil is the major insect pest in alfalfa fields and codling moth in orchards. Because of the frequent occurrence of $H$. bacteriophora and other EPN in these two habitats it is possible that these insects are amongst their natural hosts. Accordingly, the isolated steinernematids and heterorhabditids will be evaluated in the future for their control potential against these and other target pests.

In our study, the month in which samples were collected had a statistically significant effect on the proportion that was positive for EPN. The highest proportion of positive samples were taken in spring (April and May) followed by autumn (September, October) and then summer. As we conducted sampling only once per site, and not during successive seasons, our results may be due partly to the characteristics of the particular regions and sites that were chosen for sampling in each month. However, the pattern of EPN recovery is, as expected, based on seasonal weather patterns. In north-west Iran, winters are cold with heavy snowfall and subfreezing temperatures during December and January. Spring and autumn are relatively mild, while summers are dry and hot. Most of the relatively low annual rainfall occurs from October to April. Spring, therefore, is the season when temperature and moisture are optimum for EPN activity and survival, and populations of potential hosts are also high. With the onset of the hot, dry season, the EPN populations declined until autumn, when precipitation and soil moisture increased again. Brown and Gaugler (1997) demonstrated that drought can markedly delay EPN emergence from host cadavers. There is some evidence of seasonality of occurrence in different EPN surveys (Mráček, 1980; Akhurst \& Bedding, 1986; Blackshaw, 1988; Hominick \& Briscoe, 1990). By contrast, Campbell et al. (1995) and Glazer (1996) reported an absence of seasonal fluctuation in EPN densities. Moisture, temperature and host frequency are the most important abiotic and biotic factors affecting EPN density and distribution, but factors that affect EPN population dynamics are still poorly understood (Půža \& Mráček, 2005).

Soil type is one of the most important factors affecting EPN distribution in soil. Generally, soils with high sand and low clay content yield more positive results. In our survey the majority of positive samples were sandy-clayloam and sandy loam. Similar results were reported by a number of other researchers (e.g., Hominick \& Briscoe, 1990; Griffin et al., 1991; Liu \& Berry, 1995; Stock et al., 1999; Hazir et al., 2003a). Clay soil yielded negative results in our survey. Nematodes have a poor survival rate in clay soil due to smaller soil pores.

Based on these findings in the northwest of the country and the multiplicity of climatic zones in Iran, we predict that more species and possibly new species may be discovered in future surveys of Iran.

\section{Acknowledgements}

The senior author gratefully acknowledges Dr Byron J. Adams from Brigham Young University, Provo, UT, USA, for valuable suggestions and comments during this project. 


\section{References}

AdAms, B.J., Fodor, A., Koppenhöfer, H.S., StACKeBRAndT, E., Stock, S.P. \& Klein, M.G. (2006). Biodiversity and systematics of nematode-bacterium entomopathogens. Biological Control 37, 32-49.

AKHURST, R.J. \& BEDDING, R.A. (1986). Natural occurrence of insect pathogenic nematodes (Steinernematidae and Heterorhabditidae) in soil in Australia. Journal of the Australian Entomology Society 25, 241-244.

BEDDING, R.A. \& AKHURST, R.J. (1975). A simple technique for detection of insect parasitic rhabditid nematodes in soil. Nematologica 21, 109-110.

BLACKSHAW, R.P. (1988). A survey of insect parasitic nematodes in Northern Ireland. Annals of Applied Biology 113, 561-565.

Boemare, N.E., Akhurst, R.J. \& Mourant, R.G. (1993). DNA relatedness between Xenorhabdus spp. (Enterobacteriaceae), symbiotic bacteria of entomopathogenic nematodes, and a proposal to transfer Xenorhabdus luminescens to a new genus, Photorhabdus gen. nov. International Journal of Systematic Bacteriology 43, 249-255.

BROWN, I.M. \& GAUGLER, R. (1997). Temperature and humidity influence emergence and survival of entomopathogenic nematodes. Nematologica 43, 363-375.

Campbell, J.F., Lewis, E.E., Yoder, F. \& Gaugler, R. (1995). Entomopathogenic nematodes (Heterorhabditidae and Steinernematidae) seasonal population dynamics and impact on insect populations in turfgrass. Biological Control 5, 598-606.

CHOO, H.Y., KAYA, H.K. \& StOCK, S.P. (1995). Isolation of entomopathogenic nematodes (Steinernematidae and Heterorhabditidae) in Korea. Japanese Journal of Nematology $25,44-51$.

GLAZER, I. (1996). Survival mechanisms of entomopathogenic nematodes. Biocontrol Science and Technology 6, 373-378.

Glazer, I., LIRAN, N. \& STEINBERGER, Y. (1991). A survey of entomopathogenic nematodes (Rhabditida) in the Negev desert. Phytoparasitica 19, 291-300.

Grewal, P.S., Selvan, S. \& GAUGler, R. (1994). Thermal adaptation of entomopathogenic nematodes: niche breadth for infection, establishment, and reproduction. Journal of Thermal Biology 19, 245-253.

GRIFFIN, C.T. \& DownES, M.J. (1994). Recognition of low temperature active isolates of entomopathogenic nematode Heterorhabditis spp. (Rhabditida: Heterorhabditidae). Nematologica 40, 106-115.

GrIFFIN, C.T., MOORE, J.F. \& Downes, M.J. (1991). Occurrence of insect-parasitic nematodes (Steinernematidae, Heterorhabditidae) in the Republic of Ireland. Nematologica 37, 92-100.

Griffin, C.T., O'Callaghan, K.M. \& DiX, I. (2001). A self-fertile species of Steinernema from Indonesia: further evidence of convergent evolution amongst entomopathogenic nematodes? Parasitology 122, 181-186.

HAZIR, S., StOCK, S.P., KAYA, H.K., KopPenhöFer, A.M. \& KESKIN, N. (2001). Developmental temperature effects on five geographic isolates of the entomopathogenic nematode Steinernema feltiae (Nematoda: Steinernematidae). Journal of Invertebrate Pathology 77, 243-250.

HaziR, S., Keskin, N., Stock, S.P., KaYA, H.K. \& OZCAN, S. (2003a). Diversity and distribution of entomopathogenic nematodes (Rhabditida: Steinernematidae and Heterorhabditidae) in Turkey. Biodiversity and Conservation 12, 375-386.

HaziR, S., Stock, S.P. \& Keskin, N. (2003b). A new entomopathogenic nematode, Steinernema anatoliense $\mathrm{n}$. sp. (Rhabditida: Steinernematidae), from Turkey. Systematic Parasitology 55, 211-220.

HoMINICK, W.M. (2002). Biogeography. In: Gaugler, R. (Ed.). Entomopathogenic nematology. Wallingford, UK, CABI Publishing, pp. 115-143.

Hominick, W.M. \& BRISCOE, B.R. (1990). Occurrence of entomopathogenic nematodes (Rhabditida: Steinernematidae and Heterorhabditidae) in British soils. Parasitology 100, 295-302.

Hominick, W.M., Reid, A.P., Bohan, D.A. \& Briscoe, B.R. (1996). Entomopathogenic nematodes - biodiversity, geographical distribution and the convention on biological diversity. Biocontrol Science and Technology 6, 317-331.

HoMinick, W.M., BRISCOE, B.R., DEL PINO, F.G., Heng, J.A., Hunt, D.J., Kozodoy, E., MraČek, Z., Nguyen, K.B., Reid, A.P., Spiridonov, S., Stock, S.P., Sturhan, D., Waturu, C. \& Yoshida, M. (1997). Biosystematics of entomopathogenic nematodes: current status, protocols and definitions. Journal of Helminthology 71, 271-298.

Iraki, N., Salah, N., Sansour, M.A., Segal, D., Glazer, I., JohnigK, S.A., Hussein, M.A. \& Ehlers, R.-U. (2000). Isolation and characterization of two entomopathogenic nematode strains, Heterorhabditis indica (Nematoda, Rhabditida), from the West Bank, Palestinian Territories. Journal of Applied Entomology 124, 271-380.

Joyce, S.A., Reid, A., Driver, F. \& Curran, J. (1994). Application of polymerase chain reaction (PCR) methods to identification of entomopathogenic nematodes. In: Burnell, A.M., Ehlers, R.-U. \& Masson, J.P. (Eds). Proceeding of Symposium \& Workshop, St Patrick's College, Maynooth, Co. Kildare, Ireland. European Commission, DGXII, Luxembourg, pp. 178-187.

KAYA, H.K. \& GaUgler, R. (1993). Entomopathogenic nematodes. Annual Review of Entomology 38, 181-206.

KAYA, H.K. \& STOCK, S.P. (1997). Techniques in insect nematology. In: Lacey, L.A. (Ed.). Manual of techniques in insect pathology. Biological Techniques Series. San Diego, CA, USA, Academic Press, pp. 281-324. 
LIU, J. \& BERRY, R.E. (1995). Natural distribution of entomopathogenic nematodes (Rhabditida: Steinernematidae and Heterorhabditidae) in Oregon soils. Environmental Entomology 24, 159-163.

LIU, J. \& BERRY, R.E. (1996). Heterorhabditis marelatus $n$. sp. (Rhabditida: Heterorhabditidae) from Oregon. Journal of Invertebrate Pathology 67, 48-54.

MRÁČEK, Z. (1980). The use of 'Galleria traps' for obtaining nematode parasites of insect in Czechoslovakia (Lepidoptera; Nematoda, Steinernematidae). Acta Entomologica, Bohemoslov 77, 378-382.

MRÁČEK, Z. \& BECVAR, S. (2000). Insect aggregations and entomopathogenic nematode occurrence. Nematology 2, 297301.

NGUYen, K.B. \& SMART JR, G.C. (1995). Scanning electron microscope studies of Steinernema glaseri (Nematoda: Steinernematidae). Nematologica 41, 183-190.

ÖZER, N., KesKIN, N. \& KIRBAS, Z. (1995). Occurrence of entomopathogenic nematodes (Steinernematidae: Heterorhabditidae) in Turkey. Nematologica 41, 639-640.

Phan, K.L., Subbotin, S.A., NGuYen, N.C. \& Moens, M. (2003). Heterorhabditis baujardi sp. n. (Rhabditida: Heterorhabditidae) from Vietnam and morphometric data for H. indica populations. Nematology 5, 367-382.

POINAR JR, G.O. (1967). Description and taxonomic position of the DD-136 nematode (Steinernematidae; Rhabditoidea) and its relationship to Neoaplectana carpocapsae Weiser. Proceedings of Helminthological Society of Washington 34, 199-209.

POINAR JR, G.O. (1976). Description and biology of a new insect parasitic rhabditoid, Heterorhabditis bacteriophora $\mathrm{n}$. gen. n. sp. (Rhabditida: Heterorhabditidae n. fam.). Nematologica 21 (1975), 463-470.

POINAR JR, G.O. (1990). Taxonomy and biology of Steinernematidae and Heterorhabditidae. In: Gaugler, R. \& Kaya, H.K. (Eds). Entomopathogenic nematodes in biological control. Boca Raton, FL, USA, CRC Press, pp. 23-61.

PosAdA, D. \& CRANDAll, K.A. (1998). MODELTEST: testing the model of DNA substitution. Bioinformatics 14, 817-818.

PŮŽA, V. \& MRÁČEK, Z. (2005). Seasonal dynamics of entomopathogenic nematodes of the genera Steinernema and Heterorhabditis as a response to abiotic factors and abundance of insect hosts. Journal of Invertebrate Pathology 89, 116-122.

QIU, L., FANG, Y., Zhou, Y., PAng, Y. \& NGUYen, K.B. (2004). Steinernema guangdongense sp. n. (Nematoda: Steinernematidae), a new entomopathogenic nematode from southern China with a note on S. serratum (nomen nudum). Zootaxa 704, 1-20.
Rosa, J.S., Bonifassi, E., Amaral, J., Lacey, L.A., Simoes, N. \& LAUmond, C. (2000). Natural occurrence of entomopathogenic nematodes (Rhabditida: Steinernema, Heterorhabditis) in the Azores. Journal of Nematology 32, 215-222.

Salama, H.S. \& ABD-Elgawad, M.M. (2001). Isolation of heterorhabditid nematodes from palm tree planted areas and their implications in the Red Palm Weevil control. Journal of Pest Science 74, 43-45.

SPIRIDONOV, S.E. \& MoEns, M. (1999). Two previously unreported species of steinernematids from woodlands in Belgium. Russian Journal of Nematology 7, 39-42.

STOCK, S.P. \& KAYA, H.K. (1996). A multivariate analysis of morphometric characters of Heterorhabditis species (Nemata, Heterorhabditidae) and the role of morphometrics in the taxonomy of the species of the genus. Journal of Parasitology 82, 806-813.

STOCK, S.P., PrYor, B.M. \& KAYA, H.K. (1999). Distribution of entomopathogenic nematodes (Steinernematidae and Heterorhabditidae) in natural habitats in California, USA. Biodiversity and Conservation 8, 535-549.

StOck, S.P., CAMPBell, J.F. \& NADLER, S.A. (2001). Phylogeny of Steinernema Travassos, 1927 (Cephalobina: Steinernematidae) inferred from ribosomal DNA sequences and morphological characters. Journal of Parasitology 87, 877-889.

Sturhan, D. (1999). Prevalence and habitat specificity of entomopathogenic nematodes in Germany. In: Gwynn, R.L., Smits, P.H., Griffin, C., Ehlers, R.-U., Boemare, N. \& Masson, J.P. (Eds). COST 819 Entomopathogenic nematodes Application and persistence of entomopathogenic nematodes. European Commission, Luxembourg, DG XII, pp. 123-132.

Susurluk, A., Dix, I. \& STACKeBRANDT, E. (2002). Identification and ecological characterisation of three entomopathogenic nematode-bacterium complexes from Turkey. Nematology 3 (2001), 833-841.

SWOFFORD, D.L. (1998). PAUP*. Phylogenetic analysis using parsimony. Version 4. Sunderland, MA, USA, Sinauer Associates, $128 \mathrm{pp}$.

Thompson, J.D., Gibson, T.J., Plewniak, F., JeanmouGIN, F. \& Higgins, D.G. (1997). The CLUSTAL_X windows interface: flexible strategies for multiple sequence alignment aided by quality analysis tools. Nucleic Acids Research $25,4876-4882$.

WHITE, G.F. (1929). A method for obtaining infective nematode larvae from cultures. Science 66, 302-303.

WRIGHT, P.J. (1992). Cool temperature reproduction of steinernematid and heterorhabditid nematodes. Journal of Invertebrate Pathology 60, 143-152. 